\title{
Respiratory symptoms and atopy in children in Aberdeen: questionnaire studies of a defined school population repeated over 35 years
}

\author{
Anne Devenny, Heather Wassall, Titus Ninan, Maeda Omran, Suleman Daud Khan, George Russell
}

In westernised countries, up to a third of children currently have asthma. Part of this "epidemic" has resulted from a change in diagnostic criteria. In Aberdeen in 1964, asthma was diagnosed in 73 of $261(28 \%)$ participating children with wheeze, in 1989 in 331 of $675(49 \%),{ }^{1}$ and in 1994 in 654 of $1025(64 \%){ }^{2}$ Thus, even if the prevalence of wheeze had remained constant, the prevalence of diagnosed asthma would have increased, supporting the view that the recent increases in childhood asthma are explained by changing diagnostic fashion ${ }^{3}$ as well as changes in underlying symptoms. Although a weakness of these studies is their lack of objective measurements, such as bronchial hyper-reactivity, they do include items on suggestive symptoms and thus do not rely entirely on varying fashions in medical diagnosis.

Current trends in the prevalence of childhood asthma and asthma-like symptoms vary from clear increases in some countries to stabilisation or even a fall in others. ${ }^{4}$ We examined the situation in the United Kingdom by doing a further study in Aberdeen, using the same protocol as in $1989^{1}$ and $1994 .^{2}$

\section{Participants, methods, and results}

In May 1999, we distributed our questionnaire to the parents of all children attending primary school classes 5 to 7 (mainly aged 9 to 12 years with outliers aged 7,8 , and 13 years) in the schools that had participated in the 1964, 1989, and 1994 studies. The responses were entered into an SPSS database along with the earlier studies.

We distributed questionnaires to the parents of 4209 children; 3537 (84\%) were returned. Prevalence of asthma or wheeze and the proportion of children with respiratory symptoms reporting a diagnosis of asthma changed little, although we found small but significant increases in the diagnosis of both eczema and hay fever between 1994 and 1999 (table).

The male to female ratio for the diagnosis of asthma has narrowed considerably in the past 35 years, with almost complete disappearance of the previous male preponderance.

\section{Comment}

In Aberdeen, the prevalence of symptoms suggestive of asthma now seems to be stable. The proportion of children with symptoms in whom asthma has been diagnosed is high, suggesting that the widespread publicity given to asthma has paid off. Indeed, a higher rate of diagnosis might well be undesirable, leading to asthma drugs being given inappropriately-for instance, to children with chronic cough. ${ }^{5}$ Nevertheless, the continuing increases between 1994 and 1999 in diagnosed eczema and hay fever suggest that the tendency for children to develop allergies is still increasing, although these increases may also in part reflect changes in diagnostic fashion.

Contributors: AD, SDK, and HW shared responsibility for the planning and day to day running of the 1999 study. TN shared responsibility for the planning of the 1989, 1994, and 1999 studies and for the day to day running of the 1989 study. MO shared responsibility for the design of the 1994 and 1999 studies and for the day to day running of the 1994 study. All authors analysed the data, discussed and interpreted the results, and prepared this report. GR had overall responsibility for funding, design and supervision of the 1989, 1994, and 1999 studies. GR is guarantor.

This article was posted on bmj.com on 24 June 2004: http://bmi.com/ cgi/doi/10.1136/bmj.38139.666447.F7
Department of

Medical Paediatrics Royal Aberdeen Children's Hospital, Aberdeen AB25 2ZG

Anne Devenny specialist registrar Heather Wassall research assistant

Suleman Daud

Khan

consultant in

community

paediatrics

George Russell honorary consultant paediatrician

Birmingham Heartlands Hospital, Birmingham B9 5SS

Titus Ninan consultant paediatrician

Child Health Department, Doncaster Royal Infirmary,

Doncaster

Maeda Omran staff paediatrician

Correspondence to: G Russell

libra@ifb.co.uk

BMJ 2004;329:489-90

Prevalence of respiratory symptoms and diagnoses of asthma, eczema, and hayfever in children in Aberdeen in 1964, 1989, 1994, and 1999. Values are No $(\%)$ unless otherwise stated

\begin{tabular}{|c|c|c|c|c|c|c|c|}
\hline \multirow[b]{2}{*}{ Question } & \multirow{2}{*}{$\begin{array}{c}1964 \\
(n=2510)\end{array}$} & \multirow{2}{*}{$\begin{array}{c}1989 \\
(n=3390)\end{array}$} & \multirow{2}{*}{$\begin{array}{c}1994 \\
(\mathrm{n}=4047)\end{array}$} & \multirow{2}{*}{$\begin{array}{c}1999 \\
(n=3537)\end{array}$} & \multicolumn{3}{|c|}{ Relative risk (95\% Cl) } \\
\hline & & & & & 1989 v 1964 & 1994 v 1989 & 1999 v 1994 \\
\hline Ever had asthma? & $104(4)$ & $350(10)$ & $789(20)$ & $858(24)$ & 2.5 (2.01 to 3.08 ) & 1.9 (1.68 to 2.12$)$ & 1.2 (1.14 to 1.35$)$ \\
\hline Male to female ratio & $2.2: 1$ & $1.9: 1$ & $1.4: 1$ & $1.1: 1$ & 0.9 (0.82 to 1.11$)$ & $0.9(0.82$ to 0.99$)$ & 0.9 (0.83 to 0.99$)$ \\
\hline Wheeze in past 3 years? & $261(10)$ & $675(20)$ & $1025(25)$ & $986(28)$ & 1.9 (1.68 to 2.19) & $1.3(1.17$ to 1.39$)$ & 1.1 (1.01 to 1.18$)$ \\
\hline Male to female ratio & $1.7: 1$ & $1.4: 1$ & $1.2: 1$ & $1.1: 1$ & 0.9 (0.84 to 1.05$)$ & $0.9(0.86$ to 1.02$)$ & 0.9 (0.88 to 1.03$)$ \\
\hline $\begin{array}{l}\text { Asthma diagnosis in children with } \\
\text { wheeze in past } 3 \text { years }\end{array}$ & $73(28)$ & 331 (49) & $654(64)$ & $677(67)$ & $1.8(1.42$ to 2.16$)$ & 1.3 (1.19 to 1.42$)$ & $1.1(0.99$ to 1.12$)$ \\
\hline Shortness of breath in past year? & $136(5)$ & $341(10)$ & $753(19)$ & $703(20)$ & 1.9 (1.53 to 2.25$)$ & 1.9 (1.65 to 2.09 ) & 1.1 (0.97 to 1.17$)$ \\
\hline $\begin{array}{l}\text { Asthma diagnosis in children with } \\
\text { shortness of breath }\end{array}$ & $57(42)$ & $262(77)$ & $526(70)$ & $528(75)$ & 1.8 (1.49 to 2.53$)$ & $1.1(1.02$ to 1.18$)$ & $1.1(1.01$ to 1.215$)$ \\
\hline Persistent nocturnal cough in past 3 years? & * & 475 (14) & $1288(32)$ & 1067 (31) & * & 2.3 (2.07 to 2.50$)$ & 0.95 (0.98 to 1.01$)$ \\
\hline $\begin{array}{l}\text { Asthma diagnosis in children with } \\
\text { persistent nocturnal cough }\end{array}$ & * & $179(38)$ & $527(41)$ & $530(49)$ & * & $1.1(0.95$ to 1.24$)$ & 1.2 (1.09 to 1.31$)$ \\
\hline Ever had eczema? & $132(5)$ & $408(12)$ & $714(18)$ & $755(21)$ & 2.3 (1.89 to 2.77 ) & 1.5 (1.31 to 1.65$)$ & 1.2 (1.10 to 1.33$)$ \\
\hline Male to female ratio & $0.9: 1$ & $1.5: 1$ & $1.0: 1$ & $1.0: 1$ & 1.3 (1.03 to 1.53$)$ & $0.8(0.75$ to 0.93$)$ & 1.0 (0.88 to 1.08$)$ \\
\hline Ever had hay fever? & $81(3.2)$ & $405(12)$ & 511 (13) & 543 (15) & 3.7 (2.93 to 4.67$)$ & $1.1(0.94$ to 1.20$)$ & 1.2 (1.09 to 1.44$)$ \\
\hline Male to female ratio & $1.0: 1$ & $1.6: 1$ & $1.3: 1$ & $1.1: 1$ & $1.2(0.97$ to 1.55$)$ & 0.9 (0.83 to 1.03$)$ & 1.0 (0.86 to 1.07$)$ \\
\hline
\end{tabular}

*The question in 1964 related to recurrent rather than persistent cough. 
Funding: Grampian University Hospitals Children's Respiratory Fund, into which GR paid his earnings from drug trials, medicolegal reports, lectures, adoption medical examinations, etc. A generous donation was received in memory of Stuart Kerr.

Competing interests: None declared.

Ethical approval: Grampian Research Ethics Committee.

1 Ninan TK, Russell G. Respiratory symptoms and atopy in Aberdeen schoolchildren: evidence from two surveys 25 years apart. BMJ 1992;304:873-5

2 Omran M, Russell G. Continuing increase in respiratory symptoms and atopy in Aberdeen schoolchildren. BMJ 1996;312:34

3 Hill R, Williams J, Tattersfield A, Britton J. Change in use of asthma as a diagnostic label for wheezing illness in schoolchildren. BMJ 1989;299:898.

Ronchetti R, Villa MP, Barreto M, Rota R, Pagani J, Martella S, et al. Is the increase in childhood asthma coming to an end? Findings from three surveys of shoolchildren in Rome, Ifly Fur Respir J 2001;17:881-6.

Chang AB, Phelan PD, Carlin JB, Sawyer SM, Robets Chang AB, Phelon PD, Car JB, Saryer SM, Robertson CA. A ethasone for recurrent cough. Arch Dis Child 1998;79:6-11.

(Accepted 12 May 2004)

doi 10.1136/bmj.38139.666447.F7

\section{What is already known on this topic}

During the past 15 years, the prevalence of childhood asthma and symptoms suggestive of asthma have risen

\section{What this study adds}

The rate of rise in the prevalence of childhood asthma has slowed, although a quarter of primary school children have been diagnosed as having asthma at some time in their lives

Most of the recent increase can be attributed to increased diagnosis in children with symptoms; increase in wheeze is barely significant

\section{Physician, heal thyself}

When I discovered my husband had been having an affair for the past two years, I physically felt as if I was falling through the ground with all the feelings of disbelief, horror, and despair. I then realised that all the symptoms that patients had described to me were true-the tightening of the chest when the telephone rang, the palpitations when my husband was late home, and the nausea that made me retch in the morning and lose half a stone in weight.

I felt like some kind of automaton, as I used to arrive at the surgery with no memory of the journey apart from a vague recollection of hearing Melodrama sung by Andrea Bocelli from the car CD player while tears were streaming down my face.

Suddenly, work took on a new meaning. Although my partners offered me time off, I could not bear the loneliness of the house, and, after all, "work is therapeutic." At least, that is what I used to tell my patients in similar circumstances. As time went on, I found this was true, and I seemed to be enjoying work much more than before.

Of course, I realised it was giving me something else to focus on, but there was more than that. My patients were actually helping me. I genuinely liked most of them, and they seemed to like me too. Maybe I had simply not noticed it before, but now I seemed to draw strength from the consultations.

One young amputee confided, "You can't turn the clock back, doctor. You just have to move forward," when I asked him how he was coping.

My terminally ill patients also had something to teach me. "How are you managing?" I would ask routinely but now with renewed interest.

"Well, you know, doctor, I'm doing what you told me to do. Remember, you said to take a day at a time, treasure the little things-like listening to the rain pattering on the window pane, like spending time looking at the sunset. Well I'm doing that, and it helps." I had a vague recollection of saying something of that sort, but to think that a patient was being helped by some throwaway remark of mine was quite humbling.

I even had one patient show me a carefully folded note with a drug name on it and some notes I had written down for him: "Plan a nice thing each day, write things down." I recognised my scrawl and wondered if I had written this in desperation for something to do for another heartsink patient. Now I read it with comfort.
How had I known all this wisdom? I could not think where I had learnt it-mavbe it was a combination of homespun advice and Bella magazine hot tips. Nevertheless, it seemed to work. All those little quotations that I had previously thought were trite platitudes were immensely comforting to me now: "Another day dawns tomorrow. Count your blessings." Keeping a diary, "downloading," trying out counselling-you name it, whatever I had personally recommended to my patients, I now was trying out myself.

Even cleaning took on a new meaning-maybe I was cleaning out my old life? During one such cleaning session, I came across a book by Dale Carnegie- How to Stop Worrying and Start Living. I had previously treated this book with contempt, but now it was a great source of solace.

My patients benefited as a result-I was an expert when it came to anxiety and stress related illnesses. I was recommending books, advising swimming on the way home from work-and, for the first time, I knew what real empathy was. I knew that medicine was a wonderful job to be in and that it was a privilege to care for patients, as they in turn cared for me.

The elderly man with endless chronic complaints who said, "I love you, doctor," as he hobbled out of the door was probably more genuine than my husband, who had used to say the same phrase as he headed off to yet another "gravy train" conference he simply had to go to.

And so, gradually, I have decided not to descend into the depths of self pity and nor to slip into the role of Elaine of Astolat in Le Morte d'Arthur (dying from a broken heart). As a result, I am enjoying medicine much more. My heartache will heal in time, like any other wound, though my trust in men has been well and truly broken.

My only regret is that it took a personal crisis for me to realise how fortunate I am to be in this profession and how privileged to be an important part of so many patients' lives.

Name and address withheld

We welcome articles up to 600 words on topics such as A memorable patient, A paper that changed my practice, My most unfortunate mistake, or any other piece conveying instruction, pathos, or humour. Please submit the article on http://submit.bmj.com Permission is needed from the patient or a relative if an identifiable patient is referred to. We also welcome contributions for "Endpieces," consisting of quotations of up to 80 words (but most are considerably shorter) from any source, ancient or modern, which have appealed to the reader. 